DOI: https://doi.org/10.30525/978-9934-26-020-9-15

Fakhri Fuad Murshudli

Ph.D. in Economics, Doctoral student of the Chair of «Finance and Financial Institutions» Azerbaijan State University of Economics (UNEC)

Muslum Mursal Mursalov Ph.D. in Economics, Senior Lecturer of Chair of «Economic Regulation» Azerbaijan State University of Economics (UNEC)

\title{
ANTI-CRISIS REGULATION OF BANKING BUSINESS: CASE OF AZERBAIJAN
}

\section{Summary}

The article examines the experience of the Republic of Azerbaijan (RA) in anti-crisis regulation of the banking sector. The author reveals the current state of the banking system of RA. Its development is monitored from three time perspectives - on the eve of the crisis (2005-2007), in the crisis (2008-2009) and post-crisis periods (2010-2020). The characteristics and features of each of them are revealed. The conceptual essence of the definition of «anti-crisis management» is revealed. The factors contributing to the study of anti-crisis management (regulation) of banking activity as an independent field of scientific research, as well as the distinctive features of its methods and tools are highlighted. The article analyzes the impact of anticrisis regulation on the banking system of $R A$ in the context of the global 
economic crisis, as well as anti-crisis measures taken by the country's monetary authorities at various stages of the modern financial collapse. The authors concluded that these measures are inconsistent, and that it is necessary to further improve regulation and supervision in this area, aimed at achieving high financial stability of the banking system, primarily due to an adequate level of capitalization, optimal indicators of financial reserves and liquidity.

\section{Introduction}

The formation of a full-fledged, competitive, innovation-oriented banking system, adequate to the needs of society, is one of the key tasks of the economic policy pursued in the republic, aimed at ensuring its national sovereignty in the context of the country's integration into the global market space. It was proclaimed as one of the main goals of the Strategic Roadmap for the development of financial services in RA [1, p. 15-16]. Its implementation in the short and medium term will help to improve the quality of management, efficiency and transparency of the banking business, its competitive environment, maintain the stability and reliability of the functioning of credit institutions and, in general, achieve financial stability in the country.

During the transition period, the banking sector of RA underwent a structural and organizational transformation, the trends of which coincide with the general laws of the movement of transition countries [2, p. 147]. The rules of the banking business were updated, its efficiency increased, the costs of banks were rationalized, advanced business models were introduced, and new products and technologies that meet international standards were introduced. The result of these actions was the creation of a modern banking system in RA, capable of functioning in market conditions and adequately responding to the needs of customers, to the ongoing changes in the domestic and global economy.

The stable functioning of the banking system has been in the center of attention of the world community for a long time. This is due to the increased scale of financial globalization, more frequency of banking crises and the growth of their negative consequences. The global collapse of the financial sector, which showed the inadequacy of measures taken to ensure stability in this area, has become the main trend that determines the state of national banking systems. This crisis has demonstrated the ability to transcend national borders, and ultimately became an indicator of emerging problems. Changes taking place in the global financial markets in the last decade (increased competition, the introduction of new financial and information technologies, the offer of innovative, structured banking products, etc.) lead to increased risks and, therefore, there is a need to tighten the requirements for financial stability of financial and credit institutions. This circumstance, in turn, gave a new impetus to the improvement of the banking regulation system and, first 
of all, the development of anti-crisis management of banking activities, which led to the urgency of studying the problems, associated with them on the example of a single country, in this case, RA.

\section{Part 1. Banking system of Azerbaijan: assessments of its current state}

The positive trend caused by the general recovery of the economy and the growth of incomes of the population of RA in recent years contributed to the further improvement of its banking system. It should be noted that there has been undoubted progress in the main parameters of development. This was accompanied by the strengthening of the legislative and institutional framework of this sector of the economy of the republic, the establishment of banking regulation and supervision, bringing them in line with international best practice. ${ }^{1}$ Domestic banks are actively introducing international standards of corporate governance and reporting forms. The banking system infrastructure was strengthened; increased attention was paid to the use of advanced technologies and the use of the latest information and management systems. The offer of innovative banking products and services has intensified.

At the same time, despite the improvement of the situation in the banking sector of RA, its state cannot be overestimated. The SWOT analysis of the domestic banking sector shows that, along with a number of positive aspects, there are still many problem points, which, to one degree or another, have a negative impact on its stability. ${ }^{2}$ In various periods - before, during and after the global financial crisis - this factor is manifested differentially. Therefore, given the volatility of the modern financial market, we characterize the development of the banking system of RA on the basis of international assessments in three time angles - on the eve of the crisis (2005-2007), the crisis (2008-2009) and the post-crisis periods (2010-2020). The topicality in this case of international assessments of national banking systems is primarily due to the fact that the information obtained through them can be taken into account when developing and substantiating various promising strategic programs, including anti-crisis measures.

On the eve of the crisis. Positive changes in the monetary system of RA were noted by the European Bank for Reconstruction and Development (EBRD). Nevertheless, the EBRD index in assessing the reform of the country's banking sector for seven years (since 2001), has not changed 2.3 (with the maximum estimate $-4+$ ). The need to strengthen supervision in the banking sector was also pointed out [6, pp. 6, 8, 103, 211].

At the rate to the international rating agency Fitch Ratings [7; 8], the country's banking system was assigned the highest risk category - «MPI 3», which characterized domestic banks as the most unstable to changes in the

\footnotetext{
${ }^{1}$ This, in particular, was indicated in the reports of Standard \& Poor's [3, p.9; 4, p. 4, 9].

${ }^{2}$ For more on this, see [5, pp. 77-79].
} 
macroprudential situation. In the matrix of systemic risks Fitch, RA was assigned to the lowest category of the banking system indicator (BSI) - E3 [7, p. 2]. In general, the banking system of the republic was regarded as very weak, unstable, having a high level of vulnerability in terms of macroprudential indicators and a low ability to withstand the impact of macroprudential stress factors [7, p. 3; 8].

In the opinion of Fitch Ratings analysts, the country's small-scale banking sector is distinguished by a significant concentration by industries and debtors, a high degree of dollarization, a slow development of the branch network, and a low level of banking services penetration (at the end of $2007-18 \%$ ). As systemic risks, attention was focused on the high degree of state participation, the slow progress of privatization, a moderate share of foreign ownership, low return on capital, as well as insufficient levels of capitalization and transparency [9, p. 2-5].

Experts of the international rating agency Standard \& Poor's (S\&P) believe that in the pre-crisis years, the banking sector of RA expanded due to the rapid growth of external borrowings (their share in receipts from the current account increased from $14.5 \%$ in 2003 to $43.5 \%$ in 2007). This led to the rapid growth of domestic lending (in 2001-2008, on average 61\% per year with a low starting base), which, in turn, stimulated high economic activity in the non-oil sectors. After an unexpected change in the conjuncture of the world credit market, the level of net external debt of the banking system decreased and in 2008-2009 was less than $25 \%$ [10, p. 2-3].

According to the annual cross-country study «Index of Economic Freedom» (IEF), by mid-2007, in terms of the level of financial freedom RA occupied 130-144 places in the world, having received 30\% [11, p. 9-13]. Despite the reforms carried out in the republic over these years, their scale and depth turned out to be insufficient to allow it to improve the rating on the liberality of the financial and banking sector of the economy. Among the bottlenecks there were its weakness, inefficiency, burdened by bad loans, a significant volume of non-bank cash payments, insufficient lending to private entrepreneurship and non-oil industries in the absence of a deficit of credit resources, excessive credit risks, low capitalization of banks, high share of which belongs to states, weak presence in the country of branches and offices of foreign banks [11, p. 92]. The limited scale of development of the domestic banking sector is also evidenced by the low indicators of the share of banking assets and loans to the real economy in GDP.

In the Global Competitiveness report among the most problematic aspects for the country's banking system, the stability of banks, restrictions on capital movement, access to loans and foreign exchange regulation were highlighted [12, p. 10, 96-97].

The crisis period. In general, according to the EBRD, the financial system of RA was little affected by the global liquidity crisis [13, p. 100]. The direct impact of the latter on the domestic banking sector turned out to be relatively 
small due to the limited integration with international financial markets [14, p. 140]. An identical conclusion was made by the International Monetary Fund (IMF) [15]. The IMF has included RA in the group of countries, the economies of which are most resistant to global shocks and the least vulnerable to external factors [16, p. 84]. At the same time, the banking system stands out, for strengthening of which, as the IMF experts note, serious steps have been taken in the republic [17, p. 30].

The same conclusion was reached by the Russian experts, for example, A. Kudrin, who stressed that RA is experiencing the least impact of the global crisis, while maintaining high volumes of investment and economic growth [18]. In professional reviews, it was retrospectively stated that, although the domestic banking system is one of the least developed, in general, Azerbaijani banks survived the crisis best of all among the countries of Eastern Europe and the CIS [19, p. 6].

Against the background of the instability of financial markets, within the framework of the above-mentioned GCI, in 2008 in the ranking of the world's banking systems, RA moved 10 positions forward [12, p. 97; 20, p. 79]. In 2009, its position on this indicator deteriorated somewhat - a fall by 10 steps (114th place) [21, p. 89].

In The Banker's 2009 World Financial Health Index [22, p. 63-64, 66] according to the parameter «Financial sector stability» related to the banking sector, RA is located noticeably higher than many leading countries of the world - in 54th place among 184 countries. ${ }^{1}$ Moreover, it should be emphasized that in this rating, unlike all other well-known international comparative studies, The Banker applied a new model of financial risks and methods for their assessment, objectively reflecting the ability of countries to overcome the current crisis [23, p. 152-156].

International rating agencies, also pointing out as a positive fact that the republic's banking system is less susceptible to global collapse than in other CIS countries and Central and Eastern Europe [24; 25], consistently increased the number of rated domestic banks. The factors that influenced, according to the estimates of international rating agencies, the economic and industry risks of the banking system of RA in the context of the global financial and economic crisis are comprehensively covered in [23, pp. 376-377].

Post-crisis period. Whereas the increasing dependence of the development of the monetary system of RA on world prices for hydrocarbons in the context of global turbulence, we will divide this period of time into three stages: the cycle of stability in the foreign exchange market (2010-2014), the devaluation period (2015-2016) and current trends (2017-2020).

2010-2014. Despite the global financial crisis of 2008-2009, the banking system of RA in the next five years has demonstrated sufficient adaptability to

\footnotetext{
1 The named parameter is based on 5 indicators: Bank regulatory capital to risk weighted assets (100 points); Bank capital to assets; Non performing bank loans; Bank provisions/non performing loans, \%; Domestic credit provided by the bank sector (all - 25 points each) [22, p. 63].
} 
economic shocks in world markets. It is no coincidence that, unlike similar systems in some other CIS countries, it has avoided a massive withdrawal of deposits and a large-scale withdrawal of foreign investment [3, p. 10]. It is for this reason that the republic, with relatively insignificant losses, survived the global financial and economic collapse and practically did not face the problem of overcoming the shocks associated with them. In this cycle, the realities of the global financial crisis urgently demanded transformation and toughening of criteria for assessing the stability and reliability of banking systems.

Thus, the EBRD focused on the fragmentation and inefficiency of the banking system of RA, stated the presence of significant unsolved problems in it, both in terms of market structure and market institutions [26, p. 102]. To maintain financial stability, the IMF recommended a prompt solution to the issues of liquidity and sufficiency of own bank capital [27]. Against the background of an improvement in the country's position in the global competitiveness rating, a sharp deterioration in its position in terms of the banking system stability factor is noticeable (from 114th place in 2009 to 135th place in 2010 and 133rd in 2011), while of the post-Soviet countries, RA was ahead of only Ukraine [21, pp. 88-89; 28, pp. 106-107, 485; 29 , pp. 98-99, 483]. In our opinion, this was due, first of all, to a significant deterioration in the stability of the country's backbone bank - International Bank of Azerbaijan (IBA), which, naturally, had a negative impact on all aspects of the functioning of the domestic banking system and its estimated parameters within the GCI.

The compilers of the IEF, noting the measures taken by the CBA to support and stabilize the banking system, the outstripping growth of private banks relative to state-owned ones, as a «ballast» highlighted the limited long-term financial instruments for small and medium-sized businesses, which significantly hinders their development [30, p. 90; 31, pp. 8-12]. On credit availability indicator, the World Bank gave the worst performance in the entire history of the rankings Doing Business [32, p. 148; 33, p. 80].

In the post-crisis period, the banking sector of RA continued to be under the scrutiny of international rating agencies (Table 1). The generalization of their assessments led to the resulting conclusion that this sector has the potential to successfully respond to external risks and has significant reserves for its further improvement. 


\section{Factors affecting the risks of the banking system of Azerbaijan in the post-crisis period}

\begin{tabular}{|l|}
\hline \multicolumn{2}{|c|}{ POSITIVE FACTORS } \\
\hline «Fitch Ratings» \\
1. Stabilization of banks' creditworthiness \\
indicators relative to the height of the global \\
crisis. \\
2. Asset quality and liquidity in the banking \\
sector are supported by high prices for \\
hydrocarbons. \\
3. Continued slow recovery of the banking \\
system, supported by generally comfortable \\
liquidity due to the rapid growth of the retail \\
deposit base. \\
4 . Mitigating refinancing risks due to the \\
receipt of non-client funding mainly from \\
government and international financial \\
organizations. \\
«Moody's Investor Services»
\end{tabular}

\section{«Moody's Investor Services»}

1. The relatively stable macroeconomic situation has a favorable effect on the position of banks, and the low level of financial intermediation provides an opportunity for long-term growth.

2. A favorable operating environment for banks, stabilization of the quality of banking assets, liquidity, increase in profitability and capitalization.

3. Accelerating lending growth rates and increasing the share of high-yielding assets in banks' balance sheets will help to increase their profitability.

\section{«Standard \& Poor's"}

1. Good prospects for long-term macroeconomic growth.

2. High possibility of further growth of banking services penetration.

3. Azerbaijan's economy is not characterized by an increase in imbalances, which is the main factor determining the assessment of the low risk of their occurrence.

4. Azerbaijan is classified as one of the states that are ready to support the national banking system and have an effective experience in providing guarantees and maintaining liquidity in times of global turmoil.

5 . The banking sector of the country is in the phase of correction: it is forecasted that the growth rate of lending will exceed the dynamics of economic recovery.

\section{NEGATIVE FACTORS}

\section{"Fitch Ratings»}

1. Preservation of significant levels of impairment of loans issued in previous periods after high rates of their pre-crisis growth.

2. Difficulty recovering funds on problem loans due to weak corporate governance and transparency in the corporate sector, as well as the difficult situation on the real estate market.

3. Limited ability of banks to absorb losses due to limited profitability and the prevalence of moderate capitalization.

4. Lending growth is constrained by weaknesses in the corporate sector, a slowdown in real GDP growth and tighter monetary policy by the authorities.

5. Stabilization of the problem loans indicator at a high level (90 days overdue).

6. Potential for further recognition of loan impairment.

7. The negative impact on asset quality of deficiencies in the operating environment and often weak lending standards in banks.

8. The risk of applying less stringent underwriting standards in the field of SMEs and individuals due to increased competition for borrowers in this segment.

9. Moderate capitalization of many rated banks.

10. Weak generation of capital from profits due to the limited scale and high cost base of many banks.

\section{«Moody's Investor Services»}

1. High dependence of the economy on the oil sector, insufficient development of SMEs and, as a result, a limited quality client base. 2. The high level of loans to related parties in banks determines their high concentration, which is difficult to manage due to conflicts of interest.

3. A significant concentration of lending risks, as well as a high proportion of loans in foreign currency, contribute to the preservation of increased credit risks of banks and problems in their management.

4. Low average rating of financial strength of banks and high dollarization. 
6. Low level of indebtedness of the corporate sector and the population.

7. Improvement of the funding structure due to an increase in retail deposits and a slight decrease in the share of foreign funding in foreign currency.

8. The CBA has the ability to interfere in the activities of banks and take preventive measures by introducing external management and using other mechanisms. Such assistance, an adequate and timely response to the crisis made it possible to maintain a sufficient level of depositors' confidence in the country's banking system. 9. The banks of Azerbaijan demonstrate a high willingness to take risks.
5. Unsatisfactory state of risk management and underwriting in the banks of Azerbaijan. «Standard \& Poor's»

1. Concentration of the economy on the commodity sector, subject to cyclical fluctuations.

2. The quasi-fiscal activity of the CBA negatively affected the quality of assets, which manifested itself in an increase in problem loans.

3. Decrease in lending standards amid a weak payment culture of borrowers and an ineffective judicial system.

4. Low level of corporate governance and transparency.

5. Insufficient development of mortgage lending.

6. Low credit quality of many private enterprises.

7. Low lending requirements for borrowers.

8. The dominance of the state bank distorts the conditions of competition.

2015-2016. Negative metamorphoses that have occurred since the second half of 2014 due to a sharp drop in prices on the world oil market have increased pressure on the national currency rate and led to its decline. As a result, in 2015, two devaluations of the manat were carried out, which immediately affected the state of the domestic banking sector. Moreover, if, after the first devaluation, there was a dollarization of the deposit and loan portfolios of banks, then the second devaluation was accompanied by the withdrawal of funds from the banking sector against the background of a decrease in the dynamics of general economic growth. In 2015, the backbone bank, the IBA, was on the verge of default, and in 2016 the number of banks decreased from 42 to 32. Despite their restructuring of loans, the weakening of borrowers' solvency led to an increase in credit risks and, as a result, reservation for them. This ultimately led to the loss of a part of the capital «cushion» created in previous economically favorable periods, as well as to the approach of the aggregate capital adequacy ratio to the established minimum standards $(14.7 \%$ with a decrease of $4.2 \%)$ [1, p. 9]. In this regard, in order to facilitate the prompt and complete assessment of credit risks, strengthen the financial discipline of economic entities, the formation of the main elements of the credit information exchange system began. At the same time, the sector's lending activity decreased, losses associated with deterioration in asset quality increased, and the tendency to withdraw deposits from banks increased. Along with this, in order to create an effective and stable financial system, maintain financial stability, a single regulatory body was organized - the Financial Market Supervision Chamber of RA. 
2017-2020. More than 4 years after two devaluations of the national currency, the banking sector of Azerbaijan is in the stage of recovery. After the change of the mega-regulator (the CBA instead of the Chamber, which was liquidated in November 2019), work on the rehabilitation of the banking sector and its backbone structures continued. The IBA restructuring processes have come to an end. The shareholders of Azerbaijani banks provided capital injection in a total volume of more than 1.2 bln USD. The total number of currently operating banks was 26 , that is, 16 banks lost their licenses, while the facts of their consolidation were not recorded. The aggregate capital of the banking sector of Azerbaijan increased by almost $1 / 3$ and reached 1.3 bln USD, and the capital adequacy was $12.7 \%$, which is $10 \%$ higher than the normative level [34, p. 66]. As for the international aspect of domestic banking, there is actually a weakening of globalization manifestations. This is manifested in a sharp reduction in foreign subsidiary banks, branches and representative offices of domestic banks (primarily, IBA); reducing the share of foreign capital in the banking sector of Azerbaijan; complete elimination of the favorable beginnings of the prospects for the development of Islamic banking on the basis of the IBA, which developed in the republic until mid-2015; the weakening of cooperation with the world's leading rating companies, as well as the weak presence of the banks of Azerbaijan in prestigious international financial ratings.

\section{Part 2. Anti-crisis management of banking activity: conceptual component}

Before proceeding to the analysis of modern anti-crisis management measures and the use of its promising areas of improvement, it is necessary to reveal the conceptual essence of this definition. In this regard, we will consider the concept of «crisis management» in relation to banking, which will make it possible to transfer the basic principles of managing the banking sector of the economy (Table 2).

It should be noted that the presented list of definitions is far from complete, since each author in his or her work tries to reveal one or another side of the term under consideration, depending on the accents. At the same time, against the general background of a variety of different points of view, the concept of anti-crisis management is most fully revealed in [52], where it is considered in broad and narrow meanings. In a broad sense, anti-crisis management is the systemic management of an economic object at a particular level of the economy, from the point of view of countering a crisis. In a narrow sense, anti-crisis management is a system of organizational and managerial measures in relation to an individual enterprise that has fallen into a state of crisis, which is usually expressed in insolvency, which, in the event of its protracted insurmountable nature, is neutralized through bankruptcy procedures. For anti-crisis management in the narrow sense, the establishment of the fact of the financial insolvency of the enterprise officially regulated by law is of great importance. 


\section{Approaches to the definition of the concept of «anti-crisis management»}

\begin{tabular}{|c|c|}
\hline Authors & Definitions \\
\hline Blank I. [35] & $\begin{array}{l}\text { Part of the bank's overall financial strategy, which consists in } \\
\text { developing a system of tools for early diagnosis of the threat of } \\
\text { bankruptcy and its recovery from the crisis. }\end{array}$ \\
\hline Gradov A.[36] & $\begin{array}{l}\text { The aggregate of actions and a sequence of management decisions } \\
\text { that allow you to evaluate, analyze and develop the necessary system } \\
\text { of influencing the bank's recovery in order to prevent bankruptcy. }\end{array}$ \\
\hline $\begin{array}{l}\text { Gref G., } \\
\text { Yudaeva K. [37] }\end{array}$ & $\begin{array}{l}\text { A special system that is complex and strategic in nature and which } \\
\text { has the ability to completely eliminate temporary difficulties recorded } \\
\text { in the work of the bank. }\end{array}$ \\
\hline $\begin{array}{l}\text { Korotkov Ye. } \\
{[38, \text { c. 350] }}\end{array}$ & $\begin{array}{l}\text { Management, in which foresight of the danger of the crisis is set in a } \\
\text { certain way, analysis of its symptoms, measures to reduce the } \\
\text { negative consequences of the crisis and the use of its factors for } \\
\text { subsequent development. }\end{array}$ \\
\hline $\begin{array}{l}\text { Krutik A., } \\
\text { Muraviev A. } \\
\text { [39] }\end{array}$ & $\begin{array}{l}\text { Special, permanently organized management aimed at the most } \\
\text { prompt identification of the signs of a crisis state and the creation of } \\
\text { appropriate prerequisites for its timely overcoming in order to ensure } \\
\text { the restoration of the viability of the bank and prevent its bankruptcy. }\end{array}$ \\
\hline $\begin{array}{l}\text { Pushkar A. } \\
\text { et al. [40] }\end{array}$ & $\begin{array}{l}\text { A type of management that adheres to the principles of } \\
\text { purposefulness, complexity, usefulness, continuity, efficiency, } \\
\text { flexibility, efficacy, rationality. }\end{array}$ \\
\hline Tavasiev A. [41] & $\begin{array}{l}\text { A set of forms and methods for implementing anti-crisis procedures } \\
\text { those ensure the minimization of damage from the crisis, and also } \\
\text { help to establish control over the situation. }\end{array}$ \\
\hline Utkin E. [42] & $\begin{array}{l}\text { A component of general management uses its best techniques, means } \\
\text { and tools, focuses on preventing possible complications in the bank's } \\
\text { activities, ensuring its stable and successful business. }\end{array}$ \\
\hline Keller R. [43] & $\begin{array}{l}\text { A special form of management, the priority task of which is to } \\
\text { prevent or overcome all processes that can create a significant threat } \\
\text { to the life of the system, or even make it impossible to operate. }\end{array}$ \\
\hline $\begin{array}{c}\text { Igolkina T., } \\
\text { Dorokhova Y. } \\
{[44]}\end{array}$ & $\begin{array}{l}\text { A complex, multifaceted process, which is a set of forms and } \\
\text { methods of implementing anti-crisis procedures in relation to a } \\
\text { specific economic entity-debtor. }\end{array}$ \\
\hline Raizberg B. [45] & $\begin{array}{l}\text { Management of an enterprise, organization, which aims to overcome or } \\
\text { prevent a crisis state, manifested in insolvency, bankruptcy, loss-making. }\end{array}$ \\
\hline $\begin{array}{l}\text { Orekhov V. } \\
\text { et al. [46] }\end{array}$ & $\begin{array}{l}\text { The aggregate of forms and methods of implementing anti-crisis } \\
\text { procedures as applied to a specific enterprise. }\end{array}$ \\
\hline $\begin{array}{l}\text { Panova G., } \\
\text { Yarygina I. } \\
\text { [47, c. 335-336] }\end{array}$ & $\begin{array}{l}\text { A set of measures aimed at maintaining financial stability of such } \\
\text { factors as the need for anti-crisis regulation as a permanent activity; } \\
\text { complementary use of macro- and microprudential instruments, } \\
\text { ensuring, respectively, the overall financial stability and stability of } \\
\text { individual banks; accounting for the various systemic importance of } \\
\text { credit institutions; the relationship between the goals of monetary and } \\
\text { anti-crisis regulation of banking activities; development of standards } \\
\text { for banking business, along with government regulators, the banking } \\
\text { community itself in order to increase its transparency and } \\
\text { sustainability. }\end{array}$ \\
\hline
\end{tabular}


(End of Table 2)

\begin{tabular}{|c|l|}
\hline Authors & \multicolumn{1}{c|}{ Definitions } \\
\hline $\begin{array}{c}\text { Pshik B. } \\
\text { [48, p. 53] }\end{array}$ & $\begin{array}{l}\text { A set of appropriate methods, techniques and management actions } \\
\text { aimed at identifying, preventing and overcoming crisis phenomena } \\
\text { and situations in order to further ensure a stable break-even activity } \\
\text { of banking institutions. }\end{array}$ \\
\hline $\begin{array}{c}\text { Kopilyuk O. } \\
\text { et al. } \\
\text { [49, p. 20-21] }\end{array}$ & $\begin{array}{l}\text { A special type of management is interpreted in a narrow } \\
\text { to apply specific types and methods of management and is carried out } \\
\text { with the aim of diagnosing, preventing, neutralizing and overcoming } \\
\text { crisis phenomena at different levels of the banking system } \\
\text { functioning. }\end{array}$ \\
\hline $\begin{array}{c}\text { Dzhulay V. [50] } \\
\text { Kovalenko V., } \\
\text { Sytnyk M. }\end{array}$ & $\begin{array}{l}\text { A set of measures that neutralizes destabilizing factors and returns to } \\
\text { banking sector within the main parameters of its stability. }\end{array}$ \\
[51, p. 682] & $\begin{array}{l}\text { A system of management measures and decisions for diagnosing, } \\
\text { preventing, neutralizing and overcoming crisis phenomena and their } \\
\text { causes at all levels of financial management of banks, covering all } \\
\text { stages of the crisis, in particular its prevention and warning. }\end{array}$ \\
\hline
\end{tabular}

The results of the analysis lead to the conclusion that the following factors contribute to the formation of anti-crisis management (regulation) of banking activities as an independent sphere:

- The objective nature of economic cycles with periods of recession and peak of the crisis and the need in this regard to carry out countercyclical regulation.

- The possibility of a systemic banking crisis as a result of the impact of endogenous and exogenous factors not related to economic cycles

- The inability of credit institutions to return the banking system to a state of stable equilibrium in the context of systemic banking crises and the need for public administration (regulation) in order to overcome them.

- Inability to identify systemic risks in the banking sector as part of the implementation of measures to ensure the stability of individual credit institutions.

An analysis of international and domestic experience in anti-crisis management (regulation) of banking activities shows that temporary measures that are effective in a crisis period are useless to prevent future crises. According to P.S. Panova and I.Z. Yarygina, since it will hardly be possible to avoid crises in the foreseeable future, and their settlement in all cases represents activities associated with large material losses, it is necessary to develop a set of tools in advance that can be used in emergency cases without adopting special regulatory legal documents [47, p. 329-330]. Proceeding from this, anti-crisis management (regulation) activities should be permanent.

Since anti-crisis management (regulation) is a multifaceted phenomenon, it seems appropriate to consider it as a system, the elements of which are 
interconnected and interact with the elements of state policy on banking regulation.

Foreign sources note that this area is currently in the development stage. In Western practice, attempts have been made for a long time to identify methods and tools of anti-crisis management (regulation). On the contrary, they are practically not mentioned in the post-Soviet economic literature. It is important to emphasize that the already formed approaches to the definition of these methods differ significantly from each other.

According to the prevailing position in the world scientific and economic environment, the basis of anti-crisis regulation should be considered macroprudential regulation using instruments of microprudential and monetary regulation in order to achieve financial stability of the banking sector. Despite the lack of generally accepted approaches to the classification of methods and tools of anti-crisis management (regulation), we will try to highlight their characteristic features, which are most often found in foreign sources [47, p. 331-335; 53, p. 132-144; 54, p. 32-47]:

- Allocation of macro- and microprudential regulation, which have different roles in ensuring the stability of the banking system.

- The need to take into account the anti-crisis component not only in the acute phase of the crisis, but also during all other phases of the economic cycle.

- The difference between macro- and microprudential regulation from measures taken at the peak heights of the crisis in order to overcome it.

- Supplementing the two above-mentioned basic methods of anti-crisis regulation with a different set of other methods - regulation of systemically important financial institutions, including banks; banking licensing; deposit insurance system; reserve requirements; regulation of bank bankruptcy procedures; impact on the main mechanisms of the spread of the systemic crisis; regulation of excessive credit expansion; effective banking supervision.

- Use of monetary regulation instruments by central banks to ensure liquidity of the banking system during the crisis - changes in the Central Bank's interest rate; conducting operations in the open market with currency and securities; the establishment of economic norms and standards for the activities of commercial banks, etc.

\section{Part 3. Anti-crisis management of banking activities on the example of Azerbaijan}

General characteristics of the Azerbaijani economy determine its high sensitivity to external shocks. This is primarily due to the high share of the oil and gas sector, for which in 2006-2008 accounted for over 60\% of GDP. An additional factor is the high degree of financial liberalization: in 2007, Azerbaijan lifted restrictions on cross-border capital transactions. Given the macroeconomic risks, the country's leadership is pursuing a policy aimed at combining dynamic development with a cautious macroeconomic policy. 
The scope and specificity of the current global crisis required the adoption of non-standard decisions within the framework of the monetary policy of the Central Bank of Azerbaijan (CBA). Its main goals during the crisis period included providing the financial system with liquidity, supporting aggregate demand, maintaining the stability of the financial system, for which a wide range of measures were used (Table 5).

Table 3

\section{Anti-crisis policy measures in the banking sector of Azerbaijan}

$[61, p .34-35]$

Government measures

1. 50.2 million AZN was allocated from the State Budget Reserve Fund in order to increase the government's share in the authorized capital of the International Bank of Azerbaijan OJSC.

2. From January 1, 2009, the profits of banks, insurance and reinsurance companies, directed to increase the authorized capital, are exempt from income tax for a period of 3 years.

3. The income tax rate has been reduced from 22 to $20 \%$. Amendments to the Tax Code were adopted, providing for the revision of other tax rates.

4. Lending to entrepreneurship has been intensified by the National Entrepreneurship Development Fund, the agents of which are the country's commercial banks. The advantage is given to the issuance of loans in small amounts. Proposals for improving procedures have been submitted to the government.

Measures of the Central Bank of Azerbaijan

\section{On monetary policy}

1. October 14, 2008:

1.1. The discount rate has been reduced from 15 to $12 \%$.

1.2. The upper limit of the interest rate band has been reduced from 20 to $17 \%$.

1.3. Required reserve requirements for liabilities in national and foreign currencies were reduced from 12 to $9 \%$; for external liabilities of banks - from 5 to $0 \%$. Thus, the banking sector's liquid assets increased by 220 million AZN.

1.4. The average period for maintaining the level of required reserves for liabilities in national and foreign currencies increased to 1 month.

\section{October 31, 2008:}

2.1. The discount rate has been reduced from 12 to $10 \%$.

2.2. The upper limit of the interest rate band was reduced to $15 \%$; the lower limit is up to $1 \%$.

\section{December 1, 2008:}

3.1. The discount rate has been reduced from 10 to $8 \%$.

3.2. The upper limit of the interest rate band was reduced to $13 \%$.

3.3. The required reserves for liabilities in the national and foreign currencies from 9 to $6 \%$. Thus, the banking sector's liquid assets increased by 125 million AZN.

\section{February 1, 2009:}

4.1. The discount rate has been reduced to $5 \%$.

4.2. The upper limit of the interest rate band was reduced to $10 \%$.

4.3. The required reserve ratio for liabilities in national and foreign currencies has been reduced from 6\% to 3\%. Thus, the banking sector's liquid assets increased by 135 million AZN.

\section{February 10, 2009:}

5.1 The Central Bank has started to conduct currency swaps. 
(Continuation of Table 3)

6. March 2, 2009:

6.1. The discount rate and the upper limit of the interest rate band were reduced to 3 and $8 \%$, respectively.

6.2. Required reserve ratios for liabilities in national and foreign currencies were reduced from $3 \%$ to $0.5 \%$. Thus, the banking sector's liquid assets increased by 111 million AZN.

\section{May 25, 2009:}

7.1 The discount rate and the upper limit of the interest rate band were lowered to 2 and $7 \%$, respectively.

8. The Central Bank has intensified its operations to refinance the banking system. For 7 months of 2009, the Central Bank's loan portfolio grew 3.5 times.

9. On July 9, 2009, by the decree of the President of Azerbaijan, amendments and additions to the Law «On the Central Bank of the Republic of Azerbaijan» came into force, which increase the flexibility of the monetary policy of the Central Bank and the policy of regulating the banking system. On the basis of these amendments, the Central Bank has the right to provide loans in various currencies and for a longer period, including subordinated loans. At the same time, the Central Bank, in order to support the real sector, has the right to lend to banks on the basis of government guarantees.

10. On the basis of legislative amendments, on July 28, 2009, the «Rules for issuing loans to banks by the Central Bank of the Republic of Azerbaijan» were approved. The rules reflected the issues of monetary policy implementation, financial stability, regulation of capital adequacy problems, as well as the conditions for issuing loans to finance projects of state importance.

11. In order to support the development of domestic financial markets with the participation of the CBA, a collateral system was created in the Organized Interbank Credit Market.

\section{To preserve financial stability}

\section{April 30, 2008:}

12.1. The norms of provisioning have been increased for groups of assets: for assets under supervision - from 6 to $10 \%$; for unsatisfactory assets - from 25 to $30 \%$; for hazardous assets - from 50 to $60 \%$.

12.2. Requirements for real estate provision have been increased from 120 to $150 \%$.

\section{February 18, 2008:}

13.1. The share of subordinated debt in the total capital is limited:

13.2. The maximum amount of subordinated debt is set at $50 \%$ of Tier 1 capital.

13.3. The risk level of mortgage loans has been increased from 50 to $100 \%$.

\section{November 18, 2008:}

14.1. In accordance with the amendments made to the Rules for Issuing Loans in Banks, the requirements for supervision over the quality of the loan portfolio, for monitoring the borrower's activities, assessing the financial condition of the borrower and his or her solvency have been increased.

\section{December 17, 2008:}

15.1. The methodology for calculating the open foreign exchange position has been improved, including the clarification of off-balance sheet accounts included in the foreign exchange position, transactions with precious metals have been included.

15.2. On the basis of the additions made to the «Rules on the suspension of the accrual of interest on credit operations», the order of repayment of debts on loans on which interest is not charged has been brought into line.

16. May 8, 2009:

16.1. Flexibility was ensured in limiting the annual interest rate on insured deposits: the maximum amount of payments on them was increased from 6,000 to 30,000 AZN. 
(End of Table 3)

17. June 10, 2009:

17.1. Deposits with an interest rate of up to $15 \%$ are included in the insurance system

18. June 17, 2009:

18.1. A zero risk level is set for securities issued by the Mortgage Fund under the CBA.

19. The banks have improved the risk management system. For this purpose, ratings of its assessment have been established, risk monitoring has been strengthened on the basis of a special methodology, an action plan has been prepared to eliminate weaknesses and the process of their implementation has begun.

20. Since June 2009, mortgage lending has been resumed, which has intensified such spheres as construction, banking, insurance, appraisal, notary and real estate services, increased economic activity in the securities market and stabilized prices in the real estate market. The stabilization of prices, in turn, prevented the depreciation of the collateral for bank loans.

When implementing anti-crisis regulatory measures, requirements and recommendations must be consistent, and only under this condition they have constructive potential. In this sense, the amendments to the law on the CBA were quite consistent with the spirit of global trends in the legislation of central banks. According to the amendments adopted in 2008, the CBA, as the lender of last resort, received the right to issue loans to banks for a longer period and in various currencies, was empowered to provide subordinated loans to banks and the right to lend to banks based on government guarantees. These amendments ultimately led to the expansion of the state's presence in the economy.

The main goals of Azerbaijan's monetary policy during the crisis period included providing the financial system with liquidity, supporting aggregate demand, maintaining the stability of the financial system, for which a wide range of measures were used. As a result, only from October 2008 to the end of August 2009, the net volume of «injections» to maintain liquidity in the country's economy amounted to about 2 bln USD. Of this amount, only due to the reduction of required reserves, banks received more than $730 \mathrm{mln}$ USD. The CBA was mainly focused on maintainning the liquidity of systemically important banks (mainly for the timely servicing of their external debts).

Even before the onset of the crisis, bank regulation was directed against excessive overheating of the sector. Thus, prudential standards were established in such a way as to maintain sufficient liquidity and create additional provisions for potentially problem loans. In order to regulate credit risks, the standards of risks per borrower and the conditions for underwriting loans were revised and tightened. The conditions for the classification of assets were also tightened, the ratio of the collateral value to the loan amount was increased. Particular attention was paid to minimizing the currency risks assumed by banks. At the same time, the requirements for the degree of information disclosure and overcoming information asymmetry were increased. 
In the midst of the global crisis, in order to further capitalize banks and insurance organizations using internal resources, it was decided to exempt from taxation a part of the profit directed to capitalization. To protect the interests of depositors and stimulate the inflow of deposits into the banking system, the maximum size of the deposit subject to state insurance was increased 5 times. At the same time, the conditions limiting deposit insurance were relaxed [55, pp. 29, 34]. In Azerbaijan, based on the analysis of a whole range of macroeconomic factors, it was decided to maintain the stability of the national currency.

Our analysis of the main anti-crisis measures taken by the government of Azerbaijan during the acute phase of the crisis allows us to state that they were contradictory in nature. Despite this, the interim results of the anti-crisis measures of the government and the CBA in 2008-2009 brought the expected positive effect. Thus, the results of stress testing conducted by the CBA at the end of 2009 showed that even under the most unfavorable scenarios for the development of the macroeconomic situation, the banking system is capable of withstanding severe shocks and absorbing the resulting losses. This was due to the fact that most of the potential risks had already been recognized by banks, and adequate reserves were created to neutralize them. In addition, at that time, the banking sector of Azerbaijan occupied an intermediate (middle) position between the poles of dependence on external borrowings and, therefore, is much less susceptible to volatility in the world financial market [56, p. 340].

It is no coincidence that in the scientific developments of one of the leaders in the market of professional services in Russia, the FBK company, it is indicated that Azerbaijan effectively resisted the economic crisis [57, pp. 8, 29]. According to a study by the Russian Institute for the Post-Crisis World, the overwhelming majority of experts noted the anti-crisis leadership of Azerbaijan (along with Russia and Kazakhstan), pointing to the competent policy of the republic's leadership. Only its anti-crisis program was recognized as the most fully consistent with the range of measures proposed by the expert community, which allowed Azerbaijan as a whole to successfully contain the first wave of the crisis in its banking sector [58, pp. 11, 12, 17, 24, 27, 40, 57]. In professional reviews, it was retrospectively stated that, although the domestic banking system is one of the least developed, in general, the banks of Azerbaijan survived the crisis the best among the countries of Eastern Europe and the CIS [19, p. 6].

Now let us analyze the situation with the preparation and implementation of anti-crisis measures in the banking system after the acute phase of the crisis (2011-2019).

Firstly, in Azerbaijan, the banking market regulator (at that time - the CBA) decided to accelerate reforms and tighten requirements for credit institutions in accordance with the latest recommendations of the BCBS. By the decision of the CBA Board of July 25, 2012, the minimum size of the 
aggregate capital of existing banks, as well as the authorized capital of newly created banks, was increased 5 times - up to 50 mln AZN (63.7 mln USD). On December 29, 2015, the size of the capital adequacy ratio was reduced from $12 \%$ to $10 \%$, and the bank capital adequacy ratio of the first tier and the level of leverage (an instrument that links asset growth with capital growth) from $6 \%$ to $5 \%$. Conditions have been prepared for transferring the liquidity coverage ratio to the status of a regulatory requirement. An increase in the level of capitalization and new capital requirements should serve to strengthen and improve the quality of the capital base of banks, provide adequate immunization in relation to external risks and possible global challenges, and also limit risks and increase the resilience of the national banking sector.

Secondly, in February 2016, the Decree of the President of Azerbaijan was adopted on the creation of a mega-regulator - the Chamber for Control over Financial Markets of the Republic of Azerbaijan. In this regard, the State Securities Committee, the State Insurance Supervision Service of the Ministry of Finance and the Financial Monitoring Service under the CBA were abolished, and their regulatory and supervisory functions were accumulated in a new body. As a result, the regulatory functions in the monetary system of Azerbaijan were divided between it and the CBA. At the same time, the CBA carried out monetary policy, and the Chamber actually provided regulation and supervision over the financial and banking sector.

The creation of a mega-regulator in Azerbaijan represented by the Chamber had both positive (consolidated supervision, high-quality communication processes, a unified approach to the regulation of all segments of the financial market) and negative aspects (lack of proper practice of organizing supervision, appropriate staffing, the risk of establishing a low level of independence of the mega-regulator, weak information exchange with the CBA). As the financial crisis showed, the separation of regulation and supervision functions from the Central Bank by the creation of a separate mega-regulator turned out to be ineffective both in the post-socialist countries - Kazakhstan, Georgia, Poland, and in such economically developed countries as Belgium, Great Britain and Germany.

In general, assessing the activities of the Chamber, one should recognize it as not quite effective and in line with the practice of international financial organizations. First of all, this was confirmed by the growing level of problem loans in the country, the loss of public confidence in banks, the practical suspension of their lending operations with individuals and business structures, the weak transparency of the liquidation of credit institutions, passive participation in protecting the rights of depositors and investors, the absence of a Development Strategy the banking sector, targeted programs to improve its competitiveness and recovery. As a result, a number of functions of the Chamber were actually transferred to the newly created Financial Stability Council (under the auspices of the CBA) and the Financial Monitoring Service of the RA. The measures taken are an indirect 
confirmation of the unsatisfactory work of the Chamber in the field of effective regulation of financial markets. And, as a result, on November 28, 2019, by the order of the President of Azerbaijan, the Chamber was abolished, and its powers and property were transferred to the CBA.

Thirdly, in order to improve regulation of financial market stability, the CBA began to promote the development of financial instruments, with the help of which the arsenal for attracting liquidity by banks in the interbank market has somewhat expanded. The statistics show that the volume of bank lending to the country's economy and, accordingly, the credit multiplier do not correlate with the required reserve ratio of banks. If in March 2016 the volume of bank lending in manats in Azerbaijan was 10 bln AZN, then by June 1, 2017 this amount decreased to about 8 bln AZN. The analysis shows that the considered and subsequent periods, the ratio of the money supply to the monetary base in manats all the time remained at the level of 1.3-1.4. Such a low multiplier effect confirms the opinion that the banking system from the very beginning simply could not generate new credit money. The growth in lending over all these years was due to the growth of the monetary base, which, in turn, was caused by the inflow of petrodollars, and not at all by the generation indicated above. Meanwhile, in Russia the multiplier effect noted above was slightly higher, while in the European banking system this indicator fluctuated within 5-8. At the same time, the main internal source of resources for banks is still internal deposits of legal entities and individuals, which for the period 2015-2017 decreased significantly - by 11.8\%. Taking this into account, the problem of increasing the savings activity of the population of Azerbaijan in the medium term should be the subject of increased attention of the developers of the anti-crisis program.

Fourth, an important external source of resources for banks is to raise funds from non-residents, the required reserve ratio for which is $0 \%$. This could stimulate banks to actively attract loans abroad in foreign currency, but there are problems here, the solution of which should become an integral part of the anti-crisis program in the banking sector of Azerbaijan. First of all, after the downgrade of the international ratings of the banks of Azerbaijan, foreign loans for them rose in price. Further, in 2015-2017 the overwhelming majority of banks refused to take risks associated with possible fluctuations in the national currency rate in the medium term.

The lack of such willingness of banks to take risks was quite justified, since, according to available estimates, the strengthening of the dollar in the medium term by only $10 \%$ in relation to the current exchange rate of the national currency could cost the domestic banking system losses of up to 700 mln AZN. The current situation indicated that the established norms of required reserves on borrowed funds and changes in the CBA discount rate in the banking system of Azerbaijan did not work properly. Even a fivefold increase in the discount rate during 2016 and its maintenance for a long period at the level of $15 \%$ did not contribute to a decrease in the high level of 
inflation, but, on the contrary, led to a detrimental effect on domestic demand, which had stalled since 2015.

In the current economic situation, in contrast to savings, the overwhelming share (up to 90\%) of monthly income per capita went to final consumption. In this regard, the total amount of savings decreased by 2017 to a minimum level (from 9.5 bln AZN in 2015 to 7.5 bln AZN in 2016, 7.6 in 2017, 8.4 in 2018, 8.6 bln AZN in 2019). In this regard, it should be emphasized that in Azerbaijan, the monetary authorities are focusing on regulating inflation, which is not associated with the optimization of two other factors - an increase in the population's income and a reduction in unemployment (creation of new jobs). In our opinion, this feature should find its solution when developing anti-crisis measures.

And, finally, there is a need for new institutions and mechanisms to ensure the full functioning of the banking system. It should be noted that this issue is at the forefront of the action plan developed in 2017 to improve the business environment and increase the country's international rating. A number of specific measures have already been implemented in this direction. The megaregulator has already been mentioned above. Another example: in 2019 alone, the CBA made a decision eight times to cut the discount rate, which was associated with the stabilization of oil prices, low inflation and a stable macroeconomic situation. So, on February 1, the discount rate was reduced from $9.75 \%$ to $9.25 \%$, and then - almost monthly - it decreased each time by $0.25 \%$ and amounted to $7.5 \%$ by the end of the year.

The current stabilization of the manat, control over inflation and the growth of strategic foreign exchange resources have put forward as the main tasks the improvement of entrepreneurs' access to financial resources, restoration of the economic balance between the real and financial sectors, strengthening the stability of banks and stimulating, thereby, de-dollarization of the economy. Their implementation dictates the need to expand government support for small and medium-sized businesses in need of credit resources. In particular, the distribution of risks between the parties in investment projects, the replacement of the requirement for collateral with alternative means and the facilitation of entrepreneurs' access to financial resources are of particular relevance. For this purpose, at the end of 2017, a Credit Guarantee Fund was created, the functional responsibilities of which include guaranteeing loans received by entrepreneurs from authorized banks in manats, and providing subsidies for part of the interest accrued on loans issued in established order. Therefore, further improvement of the work of this Fund should be reflected in the complex of anti-crisis measures.

\section{Conclusions}

1. In all periods, the banking system of Azerbaijan was influenced by a wide range of factors that determined the economic and industry risks of its development. All these factors must be taken into account when preparing the 
anti-crisis program. Comprehensive and, most importantly, their timely accounting by the country's monetary authorities would allow in the future to avoid those cataclysms that this system is experiencing at present, or to significantly mitigate their negative consequences.

2. At present, the process of formation and development of existing methods of anti-crisis regulation of banking activities is underway in the world. At the same time, attention should be focused on the uniqueness of each of them and their intended use in a specific situation to prevent or minimize the negative impact of the crisis on specific banks or the banking sector. Along with this, their complex use as a system of anti-crisis regulation testifies to the possibility of the so-called «fine tuning», which allows one or another method or their combination to be applied to the most effective solution of specific problems.

3. The current stabilization of the manat, control over inflation and the growth of strategic foreign exchange resources have put forward as the main tasks the improvement of the access of entrepreneurs to financial resources, restoration of the economic balance between the real and financial sectors, strengthening the stability of banks and stimulating, thereby, de-dollarization of the economy. Their implementation dictates the need to expand state support for representatives of small and medium-sized businesses in need of credit resources. In particular, the distribution of risks between the parties in investment projects, the replacement of the requirement for collateral with alternative means and the facilitation of entrepreneurs' access to financial resources are of particular relevance.

4. Thus, the anti-crisis policy pursued in Azerbaijan in the monetary sphere, despite certain successes, did not fully make it possible to minimize the negative consequences of the global financial crisis on the country's economy. To ensure macroeconomic stability and support sources of liquidity for economic growth against the backdrop of this global collapse, it is necessary to further improve regulation and supervision in this area, aimed at achieving high financial stability of the banking system, primarily due to an adequate level of capitalization, optimal indicators of financial reserves and liquidity.

\section{References:}

1. Strategic Roadmap for the Development of Financial Services in the Republic of Azerbaijan. (2016). Baku, 59 p.

2. Kovzanadze I. K. (2005) Tendentsii i perspektivyi razvitiya ekonomiki i bankovskogo sektora transformatsionnyih stran [Economic and Banking System Development Trends and Prospects for Countries in Transition]. Moscow: Finansyi i statistika, 304 s. (in Russian)

3. S\&P (2009) Bank Industry Risk Analysis: Azerbaijan's Young, Fragmented Banking System Increasingly Affected by Global Crisis. New York.

4. S\&P (2012) Banking Industry Country Risk Assessment: Azerbaijan. New York.

5. Murshudli F. (2008) Azerbaijan Banking System: Challenges and Prospects of Globalization. The Caucasus \& Globalization, vol. 2, no. 2, pp. 75-95.

6. EBRD (2007) Transition Report 2007: People in Transition. London. 
7. Fitch Ratings (2006) Banking Systemic Risk Report. New York.

8. Fitch Ratings (2007) Banking Systemic Risk Report. New York.

9. Fitch Ratings (2008) The Azerbaijani Banking System and Prudential Regulations. New York.

10.S\&P (2009) How Azerbaijan is Responding to the Global Economic Turmoil. New York.

11. The Heritage Foundation (2008) 2008 Index of Economic Freedom. New York.

12. WEF (2008) Global Competitiveness Report 2008-2009. Geneva.

13. EBRD (2012) Transition Report 2008: Growth in Transition. London.

14. EBRD (2009) Transition Report 2009: Transition in crisis? London.

15. IMF (2008) Azerbaijan - Aide Mémoire for the 2008 IMF Staff Visit Discussions. Washington.

16. IMF (2009) World Economic Outlook: Crisis and Recovery. Washington.

17. IMF (2009) Regional economic outlook: Middle East and Central Asia. Washington.

18. Ofitsial'nyy veb-sayt Ministerstva finansov Rossiyskoy Federatsii [Official website of the Ministry of Finance of the Russian Federation]. Available at: http://www.minfin.ru/ru/press/speech/index.php?id4=7229 (accessed 1 May 2009)

19. Sberbanka Rossii (2012) Obzor bankovskogo sektora v stranah Vostochnoy Evropyi i SNG [Banking Sector Overview in Eastern Europe and the CIS]. Moscow: Center for Macroeconomic Research, Mart, 73 p. (in Russian)

20. WEF (2009) Global Competitiveness Report 2009-2010. Geneva.

21. WEF (2010) Global Competitiveness Report 2010-2011. Geneva.

22. The Banker's 2009 World Financial Health Rating. The Banker, January, vol. 159, no. 995, pp. 62-70.

23. Murshudli F. F. (2013) Bankovskoe obsluzhivanie vneshneekonomicheskoy deyatelnosti Azerbaydzhana $v$ usloviyah finansovoy globalizatsii [Banking Services of Foreign Economic Activities of Azerbaijan in the Conditions of Financial Globalization]. Monografiya. Baku: East-West, xvi, 416 p. (in Russian)

24. FitchRatings (2009) Azerbaijani Banks: Back Down to Earth. New York.

25.S\&P (2009) How Azerbaijan is Responding to the Global Economic Turmoil. New York.

26. EBRD (2010) Transition Report 2010: Recovery and Reform. London.

27. IMF (2012) IMF Executive Board Concludes 2011 Article IV Consultation with Azerbaijan. Public Information Notice. 12/2. Washington.

28. WEF (2011) Global Competitiveness Report 2011-2012. Geneva.

29. WEF (2012) Global Competitiveness Report 2012-2013. Geneva.

30. The Heritage Foundation (2011) 2011 Index of Economic Freedom. New York.

31. The Heritage Foundation (2012) 2012 Index of Economic Freedom. New York.

32. IBRD/WB (2010) Doing Business in 2011: Making a Difference for Entrepreneurs. Washington, vi, $255 \mathrm{p}$.

33. IBRD/WB (2012) Doing Business in 2012: Doing Business in a More Transparent World. Washington.

34. Cabinet of Ministers of the RA (2019) Report on the activities in 2018. Baku.

35. Blank I.A. (2014) Finansovyiy menedzhment. Uchebnyiy kurs [Financial management. Training course]. Kiev: Elga, Nika-Center, 656 p. (in Russian)

36. Gradov A. P. (2012) Ekonomicheskaya strategiya firmyi [Economic strategy of the firm]. Moskva: Spetsialnaya literatura, 2012, 589 p. (in Russian)

37. Gref G., Yudaeva K. (2009) Rossiyskaya bankovskaya sistema v usloviyah krizisa [Russian banking system in a crisis]. Voprosy Ekonomiki, no. 7, pp. 4-14.

38. Korotkov E. M. (2012) Antikrizisnoe upravlenie [Anti-crisis management]. Moscow: INFRA-M, 620 p. (in Russian)

39. Krutik A. V., Muravev A. I. (2011) Antikrizisnyiy menedzhment: Preventivnyie metodyi upravleniya [Crisis Management: Preventive Management Practices]. SanktPeterburg: Piter,, 430 p. (in Russian) 
40. Pushkar A. I., Trided A. N., Kolos A. L. (2011) Antikrizisnoe upravlenie: modeli, strategii, mehanizmyi [Anti-crisis management: models, strategies, mechanisms]. Kharkov: Model Vselennoy, 452 p. (in Russian)

41. Tavasiev A. M. (2012) Antikrizisnoe upravlenie kreditnyimi organizatsiyami: uchebnoe posobie [Anti-crisis management of credit institutions: a tutorial]. Moscow: Yuniti-Dana, 474 p. (in Russian)

42. Utkin E. A. (2012) Antikrizisnoe upravlenie [Anti-crisis management]. Moscow: EKMOS, 400 p. (in Russian)

43. Antikrizisnoe upravlenie [Anti-crisis management] (2012) Moscow: Yuniti-Dana, 416 p. (in Russian)

44. Igolkina T. N., Bezuglova Yu. V. (2018) Antikrizisnoe upravlenie: uchebnoe posobie [Anti-crisis management: a tutorial]. Belgorod: BUKEP, 380 p. [in Russian]

45. Rayzberg B. A. (2012) Sovremennyiy ekonomicheskiy slovar [Modern Economic Dictionary]. Moscow: INFRA-M, 512 p. (in Russian)

46. Antikrizisnoe upravlenie: uchebnoe posobie [Anti-crisis management: a tutorial] (2010). Moscow: Dashkov i Ko, 292 p. (in Russian)

47. Panova G. S., Yarigina I. Z. et al. (2020) Banki i bankovskiy biznes v globalnoy ekonomike: monografiya [Banks and banking business in the global economy: monograph]. Moskva: MGIMO-Universitet, 879 p. (in Russian)

48. Pshyk B. I. Antykryzove upravlinnia u finansovii diialnosti banku: teoretykometodolohichni aspekty [Anti-crisis Management in the Financial Activity of the Bank: Theoretical-methodological Aspects]. Visnyk Universytetu bankivskoi spravy, no. 2, pp. 50-54.

49. Kopyliuk O. I. et al. (2018) Mekhanizm antykryzovoho upravlinnia $v$ bankakh Ukrainy [The Mechanism of Crisis Management in Banks of Ukraine]. Lviv: SPOLOM, 268 p. (in Ukrainian)

50. Dzhulai V. O. (2011) Antykryzove upravlinnia v bankivskomu sektori ekonomiky Ukrainy [Crisis Management in the Banking Sector of the Ukrainian Economy] (PhD Thesis), Kiev, University of Banking of the National Bank of Ukraine.

51. Kovalenko, V. V., Sytnyk, M. A. (2018) Antykryzove upravlinnia u zabezpechenni finansovoi stiikosti bankiv [Anti-crisis Management in Providing Financial Stability of the Banking]. Infrastruktura rynku, no. 25, pp. 681-688.

52. Larionov I. K., Bragin N. I., Aliev A. T. (2010) Antikrizisnoe upravlenie [Anticrisis management]. Moskva: Dashkov i Ko, 292 p. (in Russian)

53. Alpatova E. S. (2006) Gosudarstvennoe regulirovanie bankovskoy sistemyi $v$ institutsionalnoy ekonomike [State regulation of the banking system in the institutional economy]. Kazan: Izd-vo Kazanskogo universiteta, 2006, 228 s. (in Russian)

54. Andryushin S., Kuznetsova V. (2012) Instrumentyi makroprudentsialnoy politiki tsentralnyih bankov [Macroprudential policy instruments of central banks]. Voprosy Ekonomiki, no. 8, pp. 32-47.

55. Rustamov E. S. (2010) Globalnyiy krizis i antikrizisnaya politika Tsentralnogo banka Azerbaydzhana [Global crisis and anti-crisis policy of the Central Bank of Azerbaijan]. Russian Journal of Money and Finance, no. 1, pp. 27-35.

56. Alekperova F. R. (2011) Globalizatsionnyie vyizovyi i antikrizisnaya politika v bankovskoy sfere [Globalization challenges and anti-crisis policy in the banking sphere]. Revival - XXI century, no. 162-163, pp. 338-348.

57. Nikolaev I. A., Marchenko T. E., Titova M. V. (2009) Stranyi SNG i mirovoy krizis: obschie problemyi i raznyie podhodyi [CIS countries and the world crisis: common problems and different approaches]. Moscow: FBK, 27 p.

58. Post-USSR: Assessing Government Anti-Crisis Actions. International Research. Moscow: Post-Crisis World Institute, February-March 2009. 70 p. 